\title{
Effects of Low, Adequate and High Dietary Zinc Intake on Metabolic Interactions between Zinc, Copper and Iron in Different Mongolian Gerbil Tissues
}

\author{
A. CEROVIC ${ }^{1}$, I. MILETIC ${ }^{1}$, D. BLAGOJEVIC ${ }^{2}$, S. SOBAJIC ${ }^{1}$, M. VASILJEVSKA ${ }^{3}$, M. POZNANIC ${ }^{4}$, \\ M. RADUSINOVIC ${ }^{1}$
}

${ }^{1}$ Department of Bromatology, School of Pharmacy, University of Belgrade, Belgrade, Serbia

${ }^{2}$ Department of Physiology, Institute for Biological Research, Belgrade, Serbia

${ }^{3}$ Department of Medical Research, Military Medical Academy, Belgrade, Serbia

${ }^{4}$ Department of Instrumental Chemistry, Centre for food Analysis, Belgrade, Serbia

Received February 26, 2007

Accepted November 15, 2007

\begin{abstract}
Cerovic A., I. Miletic, D. Blagojevic, S. Sobajic, M. Vasiljevska, M. Poznanic, M. Radusinovic: Effects of Low, Adequate and High Dietary Zinc Intake on Metabolic Interactions between Zinc, Copper and Iron in Different Mongolian Gerbil Tissues. Acta Vet. Brno 2008, 77: $17-23$.

This study examined the influence of low, adequate and high dietary zinc intake on the growth and metabolic interactions between zinc, copper and iron in different Mongolian gerbil (Meriones unguiculatus) tissues. Animals were fed a basal diet (for $3 \mathrm{wk}$ ) containing a low-zinc level (8 mg/ $\mathrm{kg}$ diet, LZ-group), adequate zinc level ( $25 \mathrm{mg} / \mathrm{kg}$ diet, AZ-group) and saturated zinc level (38 $\mathrm{mg} /$ $\mathrm{kg}$ diet, SZ-group). After comparing the body weight of gerbils, the present study demonstrated that the LZ-group $(51.68 \mathrm{~g} \pm 3.35)$ showed growth retardation, contrary to the AZ- and SZ-groups $(58.03 \mathrm{~g} \pm 2.18$ and $62.35 \mathrm{~g} \pm 2.04$, respectively). Concentrations of zinc in the liver, kidneys and testes in the LZ-group $(41.28,19.58,22.55 \mathrm{mg} / \mathrm{kg}$, respectively) were significantly lower than in the AZ-group (57.27, 23.73, $28.79 \mathrm{mg} / \mathrm{kg}$, respectively) and the SZ-group (73.06, 30.07, 34.52 $\mathrm{mg} / \mathrm{kg}$, respectively). Results also showed that copper and iron concentrations in the kidney, heart and liver were significantly higher in the LZ-group $(\mathrm{Cu} 11.45,7.01,7.95 \mathrm{mg} / \mathrm{kg}$; Fe 116.19, $126.07,299.47 \mathrm{mg} / \mathrm{kg}$ ) than in the AZ-group (Cu 8.72, 5.6, $6.5 \mathrm{mg} / \mathrm{kg} ; \mathrm{Fe} \mathrm{97.27,} \mathrm{97.27,} 250.25$ $\mathrm{mg} / \mathrm{kg}$ ) and the SZ-group (Cu 6.48, 4.15, $4.8 \mathrm{mg} / \mathrm{kg}$; Fe 74.95, 77.95, $200.27 \mathrm{mg} / \mathrm{kg}$ ). There was an increase of testis copper concentration in the LZ-group $(4.9 \mathrm{mg} / \mathrm{kg})$ compared to the AZ-and SZ-groups (3.99 and $3.05 \mathrm{mg} / \mathrm{kg}$, respectively), and there was no significant difference in testis iron concentration between animals in different diet groups. These results showed that a low-zinc diet had negative effects on growth and the concentration of zinc in the kidneys, liver and testes. This also affected homeostasis of copper and iron by increasing its distribution in the kidneys, liver and heart tissue. However, in testes only copper concentration was increased.
\end{abstract}

Homeostasis, $\mathrm{Zn}, \mathrm{Cu}, \mathrm{Fe}$, growth, kidney, liver, heart and testis tissues

Zinc is the most abundant intracellular trace element required for a number of cellular processes, including cell proliferation, reproduction, immune function and defence against free radicals. It is a constituent of more than 300 metalloenzymes (Valle and Falchuk 1993). Insufficient dietary intake of zinc causes the appearance of pathogenic features including growth retardation, dermal lesions, immunodeficiency, male and female infertility and neurosensory disorders (Cerovic et al. 2006). As a result, supplements containing zinc are used worldwide. Furthermore, excessive dietary intake of zinc can interact with other minerals and leads to imbalance of the micronutrient status. It has been recognized that zinc metabolism interacts with the metabolism of copper and iron (Reeves 1998; Linder 1996; Davidson et al. 1995). Earlier results showed that copper and iron absorption were depressed in animals and humans when they were chronically fed diets with high concentrations of zinc (Reeves et al. 1998).

This study was designed to assess the long-term effects of low, adequate and high dietary zinc intake on metabolic interactions between zinc, copper and iron in different Mongolian

Address for correspondence:

Aleksandra Cerovic

Farmaceutski fakultet

Vojvode Stepe 450

11000 Belgrade, Serbia

Fax: +381 112120466 or +381113972840

E-mail: sandracr@pharmacy.bg.ac.yu

http://www.vfu.cz/acta-vet/actavet.htm 
gerbil tissues, as well as their effect on growth. Growth was chosen as a representative indicator of the zinc functional status in these animals.

\section{Materials and Methods}

Animals and treatment

Thirty male Mongolian gerbils (weight 55 - 60 g, 9 - 10 weeks old) were used in this study. The gerbils were randomly assigned to the following three groups (10 animals each): low zinc group (LZ) fed a diet containing $8 \mathrm{mg}$ of zinc/ $\mathrm{kg}$, saturated zinc group (SZ) fed a diet containing $38 \mathrm{mg}$ of zinc $/ \mathrm{kg}$, and adequate zinc group (AZ) fed an adequate zinc diet containing $25 \mathrm{mg}$ of zinc $/ \mathrm{kg}$. The basal diet was based on Noh and Koo with egg-white as the protein source (Noh et al. 2001) according to the recommendations of the American Institute of Nutrition. The vitamins and mineral mixes were adjusted to the amount required for this species (Benevenga et al. 1995). The basal diet is adequate to support growth and weight gain in animals. In order to prepare low-, adequate- and high-zinc diets, zinc sulphate was added to the basal diet. Gerbils were given food and deionized water ad libitum throughout the 3-week experimental period. Body weight was recorded at the beginning of the experiment and then weekly during the experimental period. There were no significant differences in initial weight among the groups. On the $20^{\text {th }}$ day the feed was removed from all the gerbils at 20:00 $\mathrm{h}$ (drinking water was still available). In order to avoid any possible rhythmic influence of dietary zinc on the metabolic status of trace elements, the animals were sacrificed precisely between 08.30 and $09.00 \mathrm{~h}$ after 12-hour overnight fasting. Collected organs (liver, kidneys, heart and testes) were rinsed in deionized water, weighed and stored at $-80{ }^{\circ} \mathrm{C}$ until analyzed. The relative organ weights were calculated.

This study was performed in adherence to the ISO 10993-2 Animal Welfare Requirements for the use of experimental animals, with permission of the Ethics Committee of the Military Medical Academy.

\section{Zinc, copper and iron analysis}

Weighed amounts of tissue were digested with $65 \% \mathrm{HNO}_{3}$ (Merck) and $32 \% \mathrm{H}_{2} \mathrm{O}_{2}$ under pressure in Teflon TFM vessels in the microwave digestion system (Milestone ETHNOS PLUS labstation with HPR-1000/10S high pressure segmented rotor). After complete digestion, the clear solution was allowed to cool and transferred to a marc flask. Zinc, copper and iron were determined by flame atomic absorption spectrometry technique (FAAS). Zinc, copper and iron concentrations were measured at $213.9 \mathrm{~nm}, 324.7 \mathrm{~nm}$ and $248.3 \mathrm{~nm}$, respectively. The analysis was done on a GBC 932 plus atomic absorption spectrometer using the Photron multi-element lamp. The metal concentrations were expressed in $\mathrm{mg}$ per $\mathrm{kg}$ of tissue.

\section{Statistical analysis}

Data are expressed as the mean $\pm \mathrm{SD}$ and statistical significance of differences between groups were determined by one- and two-way ANOVA.

\section{Results}

Body weight and relative organ weight

Table 1A shows the changes in the body weight of gerbils throughout the 3 wk of dietary treatment. The gerbils in all groups grew during the first week of treatment without any significant differences between them. In the second week of treatment, the SZ-group significantly gained weight compared to the LZ- $(p<0.05)$ and AZ-groups $(p<0.01)$. The strongest effect of different concentrations of dietary zinc on body weight changes could be seen in the third week when gerbils in the LZ-group lost weight contrary to gerbils in the AZ- $(p<0.01)$ and SZ-groups $(p<0.001)$ that continued to gain weight.

Table 1A. Body weight change (A) and relative organ weights (B) in gerbils fed the low (LZ), adequate (AZ) or saturated $(\mathrm{SZ})$ zinc diet for 3 weeks $($ mean $\pm \mathrm{SD})$

\begin{tabular}{|l|c|c|c|c|}
\hline \multirow{2}{*}{ Diet } & \multicolumn{4}{|c|}{ Time (weeks) } \\
\cline { 2 - 5 } & 0 week & 1 week & 2 weeks & 3 weeks \\
\hline LZ-group & $51.55 \pm 2.95$ & $53.03 \pm 2.51$ & $58.28 \pm 1.54^{\mathrm{b}}$ & $51.68 \pm 3.35^{\mathrm{c}}$ \\
\hline AZ-group & $52.07 \pm 2.59$ & $54.95 \pm 2.22$ & $57.28 \pm 2.86^{\mathrm{b}}$ & $58.03 \pm 2.18^{\mathrm{b}}$ \\
\hline SZ-group & $53.58 \pm 1.34$ & $56.02 \pm 1.88$ & $61.44 \pm 1.62^{\mathrm{a}}$ & $62.35 \pm 2.04^{\mathrm{a}}$ \\
\hline
\end{tabular}

The changes in relative weights of the kidneys, heart, liver and testes of male gerbils during the treatment are presented in Table 1B. The present data indicate an increase in the relative weight of kidneys and liver of gerbils fed a LZ-diet compared to animals fed AZ- and SZ-diets $(p<0.001)$, and a decrease in the relative weight of testes in animals fed 
Table 1B.

\begin{tabular}{|c|c|c|c|}
\hline \multicolumn{5}{|c|}{ Relative organ weight } \\
\hline Organ & LZ-group & AZ-group & SZ-group \\
\hline Kidney $(\mathrm{g} / 100 \mathrm{~g}$ body weight) & $1.39 \pm 0.05^{\mathrm{a}}$ & $0.79 \pm 0.04^{\mathrm{b}}$ & $0.52 \pm 0.05^{\mathrm{ab}}$ \\
\hline Heart (g/100g body weight) & $0.49 \pm 0.03$ & $0.47 \pm 0.05$ & $0.45 \pm 0.01$ \\
\hline Liver (g/100g body weight) & $4.55 \pm 0.17^{\mathrm{a}}$ & $3.54 \pm 0.06^{\mathrm{b}}$ & $2.65 \pm 0.17^{\mathrm{ab}}$ \\
\hline Testes (g/100g body weight) & $1.26 \pm 0.09^{\mathrm{a}}$ & $1.47 \pm 0.12^{\mathrm{b}}$ & $1.98 \pm 0.11^{\mathrm{ab}}$ \\
\hline
\end{tabular}

All values are expressed as mean $\pm \mathrm{SD}, \mathrm{n}=10$. (A) The effects were tested by two-way ANOVA with time and diets as factors. Post-hoc comparison for each time point performed by Tukey HSD $t$-test procedure $(p<0.05$ are considered as significant). Different letters in superscript indicate significant differences. (B) $P$-values are for repeated measures one-way ANOVA adjusted with the Tukey-Kramer procedure. Significant differences are compared to AZ-group ${ }^{\mathrm{a}} p<0.05$ and LZ-group ${ }^{\mathrm{b}} p<0.05$.

a LZ-diet compared with gerbils fed AZ- and SZ-diets. There were no changes in the relative weight of heart after 3 wk of treatment with various concentrations of dietary zinc.

Zinc concentration in the kidney, heart, liver and testicular tissue

Zinc concentrations in the kidney, heart, liver and testis samples are shown in Fig. 1. Kidney, liver and testes concentrations of zinc were significantly decreased in male gerbils that were fed a LZ-diet. Hence, zinc concentrations in the kidneys, liver and testes of gerbils fed a LZ-diet were decreased by $17.5 \%, 27.9 \%$ and $21.7 \%$, respectively, compared with gerbils fed an AZ-diet. On the other hand, the diet supplemented with zinc produced a significant increase in the zinc concentration in kidney, liver and testis tissue when compared to animals fed an AZ-diet. The largest percentage of increase in the zinc concentrations was in the liver $(27.6 \%)$, then in the kidneys $(26.8 \%)$ and the lowest increase was in the testes $(19.9 \%)$ (Fig. 1). There were no significant differences in heart zinc concentrations among gerbils fed LZ-, AZ- and SZ-diets.

Copper concentration in kidney, heart, liver and testicular tissue

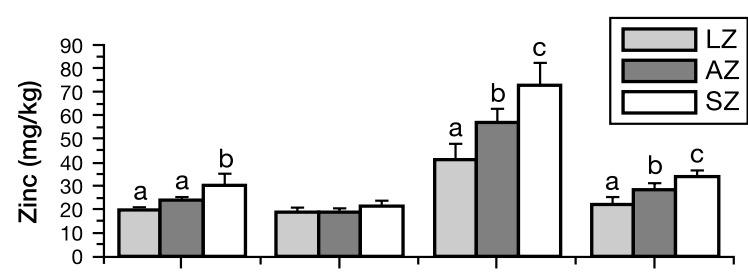

Fig. 1 shows copper concentrations in kidney, heart, liver and testes samples. Kidney, heart, liver and testes concentrations of copper were significantly increased in male gerbils that were fed a LZdiet, whereas the concentration of copper was significantly decreased
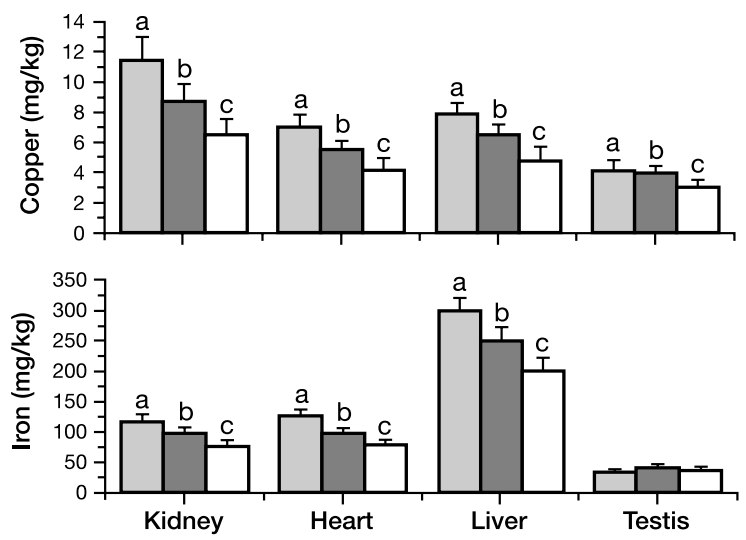
in animals fed a SZ-diet. The largest percentage of increase in the copper concentrations of gerbils fed a LZ-diet compared to animals fed an AZ-diet was in

Fig. 1. Zinc, copper and iron concentrations $(\mathrm{mg} / \mathrm{kg})$ in kidney, heart, liver and testes of male gerbils fed the low (LZ), adequate (AZ) or saturated (SZ) zinc diet for 3 weeks. All values are expressed as mean $\pm \mathrm{SD}$, $n=10$. The effects were tested by two-way ANOVA, followed by post-hoc comparison performed by Tukey HSD t-test procedure $(p<0.05$ are considered as significant). Different letters in superscript indicate significant differences.. 
the kidneys (31.34\%) and then in the heart (25.96\%), the testes $(24.99 \%)$, and the lowest increase was in the liver $(22.49 \%)$. The percentage of reduction in copper concentrations in the kidneys (25.67\%), heart (25.4\%), liver (26.29\%) and testes $(23.65 \%)$ in gerbils fed a SZ-diet was similar when compared to the AZ-group.

Iron concentration in kidney, heart, liver and testicular tissue

Concentrations of iron were also determined in kidney, heart, liver and testes samples. Our data showed that the LZ-diet produced an increase in the iron concentration in kidney, heart and liver tissues, as opposed to the SZ-diet which decreased it (Fig. 1). The percentage of increase in the iron concentrations in the kidneys, heart and liver of gerbils fed a LZdiet were $19.46 \%, 29.6 \%$ and $19.67 \%$, respectively, while the percentage of decrease in the kidneys, heart and liver of gerbils treated with a SZ-diet were $22.94 \%, 19.86 \%$ and $19.97 \%$, respectively. There were no significant differences in testicular iron concentrations between animals in different diet groups.

\section{Discussion}

This study was performed on young growing mail gerbils (Meriones unguiculatus) whose initial body weight was without significant differences. The effect of dietary zinc on the body weight found in this report was consistent with earlier reports showing growth failure in gerbils fed a LZ-diet, contrary to the groups of gerbils fed AZ- and SZ-diets (Cerovic et al. 2006). These results might be explained by the fact that growth is regulated mainly by the growth hormone (GH) and insulin-like growth factor-I (IGF-I) that are correlated with dietary zinc (MacDonald 2000; Cerovic et al. 2007). An earlier report demonstrated that zinc deficiency caused failure of GH secretion from the pituitary gland in rats (MacDonald 2000). Additionally, reduced food intake that occurred within $4-5 \mathrm{~d}$ of feeding with a zincdepleted diet resulted also in growth impairment. That was caused by reduction of protein intake that led to diminishing IGF-I production in the liver (MacDonald 2000).

The present data indicate a gradual decrease in the relative weight of kidneys and liver in gerbils fed LZ-, AZ- and SZ-diets, respectively, as well as an unchanging relative heart weight. This tendency is consistent with other reports (Sakai et al. 2004). This finding contradicts the actual increase in the body weight found in gerbils fed a SZ-diet when compared to animals fed other types of diet. The organism as a whole as well as the visceral organs (liver, kidneys) become hypertrophic in response to GH and IGF-I. However, epiphyseal cartilage, growth plates of the long bone and skeletal muscle are the main target of these hormones (Genuth 1993). Therefore, it is possible that the growth of the bone and skeletal muscle that represent the largest proportion of the body weight were more expressed than the growth of the visceral organs, such as the kidneys and liver. We concluded that a LZ-diet caused a decreased secretion of GH and IGF-I, thus causing a slower increase in the body weight. At the same time, GH could have less influence on kidney and liver so that it may seem that their relative mass increased.

The effect of dietary zinc on the relative weight of testis found in the present study was consistent with earlier reports (Martin et al. 1994), showing retardation of testis development in gerbils fed a LZ-diet. It is the result of histological changes, including an increase in the interstitial region in the testes of animals with insufficient dietary zinc intake (Martin et al. 1994).

Our data showed that animals fed a LZ-diet had significantly lower concentrations of zinc in the kidney, liver and testis tissues. Similar results were reported by other authors (Tapiero et al. 2003; Sakai et al. 2004). Previous data showed that the homeostatic mechanism was sufficient to maintain the whole body zinc content during a small change in the zinc intake by changing absorption and excretion (Tapiero et al. 2003; King et al. 2000). The results also showed that the whole body zinc content was changed by an extremely low 
or high dietary zinc intake. In severe zinc deficiency the loss was not uniform across all tissues. Zinc concentration remained constant in the hair, skin, heart and skeletal muscle, whereas plasma, liver, bone and testis zinc concentration dropped significantly (Tapiero et al. 2003). The data also showed that the highest amount of zinc was in the bone, then in the testes, liver, kidneys and skeletal muscle and less in the plasma of male rats (House et al. 1997), although compartmental analysis of zinc kinetics reported that plasma zinc exchanged rapidly with zinc in the liver, then in the bone, skeletal muscle, skin, kidneys, and less rapidly in the testes (House et al. 1997). Based on these observations we could conclude that the significant decrease in the zinc concentration in the liver, kidneys, and testes of gerbils fed a LZ-diet could be the result of the following: (1) increased absorption of zinc due to an insufficient dietary intake; (2) decreased primary faecal zinc excretion; (3) rapid exhaustion of the main body pool of zinc, such as the liver, bone and skeletal muscle; (4) slow exhaustion of zinc from the kidneys and testes.

As seen in Fig. 1, the renal zinc concentration decreased in animals fed a LZ-diet. This is consistent with the finding that initiation of a very low zinc intake caused a decline in urinary zinc (King et al. 2000). Therefore, it is possible that the amount of zinc decreased in kidney tissue.

Zinc was suggested to play a key role in mammalian spermatogenesis and growth of testes. A study performed on rats reported that low dietary zinc decreased serum and testicular levels of testosterone (Martin et al. 1994). It can be concluded that interstitial cells in testes produce less testosterone in animals fed a LZ-diet. Our results demonstrated that a LZ-diet caused low zinc content in the testes. These results support the fact that zinc plays a key role in testosterone production and spermatogenesis.

The data also showed that severe zinc depletion caused a 50\% decrease in the amount of zinc per ejaculum with a lower amount of zinc also occurring in testicular tissue (King et al. 2000). This was consistent with the previous finding that low dietary zinc resulted in low testosterone which plays a key role in spermatogenesis. This impairment can be reversed by zinc supplementation as shown by our results, i.e. zinc supplementation resulted in testis growth.

The findings that the gerbils fed a SZ-diet had a decreased copper concentration in the kidneys, heart, liver and testes compared to the gerbils fed AZ- and LC-diets were similar to previous reports (Reeves et al. 1998). The mechanism has not been completely explored, but it appears that it involves an interaction between zinc and copper at the intestinal level (Reeves et al. 1998). The primary site for copper-zinc interaction is intestinal mucosa with metallothionein (MT). This protein (MT) plays a key role in metal-related homeostasis due to the high affinity for zinc and copper (Tapiero et al. 2003). One study showed that a high dietary zinc intake induced the production of mucosal MT (Reeves et al. 1998). A high concentration of MT binds copper and prevents its absorption in the body (Linder 1996). However, another study demonstrated that MT is not absolutely necessary for the induction of a low copper status in mice fed a high zinc diet (Reeves et al. 1998). The authors suggested that the mechanism may lie in the modulation or inhibition of a $\mathrm{Cu}$-transporting P-ATPase, which transfers copper across the basolateral membrane of mucosal cells into the blood.

All the absorbed copper that entered in blood, went to the liver, kidneys (the main storage area of copper), and other visceral organs (Linder 1996). The effect of high dietary zinc on the concentration of copper in the heart was consistent with other reports that showed that perfusion with zinc also resulted in a significant increase in the excretion of copper from the heart (Tapiero et al. 2003; Zaslavsky et al. 2002). Furthermore, even moderate copper deficiency in rats reduced the activity of cytochrome $c$ oxidase in heart tissue (Linder 1996). It is a copper-containing enzyme that is the component in the electron transport chain of oxidative phosphorylation and plays a key role in energy supply (Linder 1996). 
In addition, sperm motility and seminal emission are reduced with copper deficiency, probably due to a decrease in cytochrome $c$ oxidase and less ATP availability (Morisawa et al. 1972). Thus, significantly decreased copper concentration in the testes of gerbils fed a SZ-diet could be the result of a decreasing absorption of copper and a decreasing copper excretion by seminal emission, which is regulated by homeostatic mechanisms.

As presented in Fig.1, low zinc dietary intake increased the iron concentration in the kidneys, heart and liver when compared to the gerbils fed a diet with adequate or sufficient zinc. It has been recognized that iron metabolism interacts with the metabolism of zinc and copper, which might be explained by a competitive absorption between iron and zinc (Troost et al. 2003). They competitively bind for the transport protein DMT1 (formerly called DCT1 or Nramp2), which is located at the apical membrane in the small intestine (Troost et al. 2003). An in vitro study also clearly documented the inhibitory effect of zinc on Caco-2 cells iron uptake by another mechanism different from DMT1 (Glahn et al. 2002). Absorbed iron was transported by plasma into the liver and bone marrow, which served as the main reservoir of this element (Yip et al. 1996). This might explain the high zinc concentration in the liver of animals fed a LZ-diet compared to the animals fed the AZ- or SZ-diet. Previous data showed that high dietary iron intake caused an increased loss of iron through the faeces, bile, and urine regulated by homeostatic mechanism (Yip et al. 1996). Furthermore, a high amount of iron in the kidneys was expected in animals fed a LZ-diet compared to the animals fed an AZ- or SZ-diet. Our results also showed decreased iron in the heart of animals fed a SZ-diet compared to the animals fed an AZ- or LZdiet. It might be explained by the fact that myoglobin was decreased in iron deficient rats (Yip et al. 1996). This implies not a direct, but physiological regulation of zinc and iron concentrations in tissues, depending on the role of each element in physiological processes. Significant differences in testis iron concentration among animals fed LZ-, AZ- and SZdiets were not found. This could suggest that in relation to various concentrations of a dietary zinc intake, testis present no changeable pool of iron.

The present results showed that the low zinc diet had negative effects on growth, and the kidney, liver, and testis distribution of zinc. Zinc also affected homeostasis of copper and iron by changing the distribution of these metals in the kidney, liver and heart tissue, whereas in the testes zinc influenced only copper homeostasis. Supplementation of zinc could be beneficial for growth, but attention must be paid to its metabolic interactions with other trace elements, particularly copper and iron that are also present in food.

\section{Vliv nízkých, fyziologických a vysokých dávek zinku v potravě na metabolické interakce zinku, mědi a železa v různých tkáních pískomila mongolského}

Autoři zkoumali vliv nízkých, fyziologických a vysokých dávek zinku v potravě na růst a metabolické interakce mezi zinkem, mědí a železem v různých tkáních pískomila mongolského (Meriones unguiculatus). Zvířata byla 3 týdny krmena základní dietou obsahující nízké dávky zinku ( $8 \mathrm{mg} \cdot \mathrm{kg}^{-1}$ potravy, skupina LZ), fyziologickou dávku zinku $\left(25 \mathrm{mg} \cdot \mathrm{kg}^{-1}\right.$ potravy, skupina AZ) a vysokou dávkou zinku (38 $\mathrm{mg} \cdot \mathrm{kg}^{-1}$ potravy, skupina SZ).

Po srovnání hmotností pískomilů se ukázalo, že skupina $\operatorname{LZ}(51,68 \mathrm{~g} \pm 3,35)$ zaostávala v růstu ve srovnání se skupinami AZ a SZ $(58,03 \mathrm{~g} \pm 2,18 ; 62,35 \mathrm{~g} \pm 2,04)$.

Koncentrace zinku v játrech, ledvinách a varlatech $\left(41,28 ; 19,58 ; 22,55 \mathrm{mg} \cdot \mathrm{kg}^{-1}\right)$ byly u skupiny LZ podstatně nižší než u skupiny AZ $\left(57,27 ; 23,73 ; 28,79 \mathrm{mg} \cdot \mathrm{kg}^{-1}\right)$ a SZ $(73,06$; 30,$\left.07 ; 34,52 \mathrm{mg} \cdot \mathrm{kg}^{-1}\right)$. Výsledky také ukázaly, že koncentrace mědi a železa v ledvinách, srdci a játrech byly podstatně vyšší u skupiny $\mathrm{LZ}\left(\mathrm{Cu} 11,45 ; 7,01 ; 7,95 \mathrm{mg} \cdot \mathrm{kg}^{-1} ; \mathrm{Fe} 116,19\right.$; 126,07; 299,47 mg.kg-1) než u skupiny AZ (Cu 8,72; 5,6; 6,5 $\mathrm{mg} \cdot \mathrm{kg}^{-1} ; \mathrm{Fe} \mathrm{97,27;} \mathrm{97,27;}$ $\left.250,25 \mathrm{mg} \cdot \mathrm{kg}^{-1}\right)$ a skupiny SZ (Cu 6,48; 4,15; 4,8 $\left.\mathrm{mg} \cdot \mathrm{kg}^{-1} ; \mathrm{Fe} 74,95 ; 77,95 ; 200,27 \mathrm{mg} \cdot \mathrm{kg}^{-1}\right)$. Byl také zjištěn zvýšený obsah mědi ve varlatech u skupiny $\mathrm{LZ}\left(4,9 \mathrm{mg} \cdot \mathrm{kg}^{-1}\right) \mathrm{v}$ porovnání 
se skupinami AZ a SZ $\left(3,99 ; 3,05 \mathrm{mg} \cdot \mathrm{kg}^{-1}\right)$, zatímco obsah železa ve varlatech se u jednotlivých skupin významně nelišil.

Výsledky studie prokázaly, že nízký obsah zinku v potravě ovlivňuje negativně růst a obsah zinku v ledvinách, játrech a varlatech. Byl tak ovlivněn i metabolismus mědi a železa jejich zvýšeným ukládáním v tkáni ledvin, jater a srdce. Ve varlatech byla však zvýšená pouze koncentrace mědi.

\section{References}

BENEVENGA NJ, CALVERT C, ECKHERT CD, FAHEY GC, GREGER JL 1995. Nutrient requirements of the gerbil. In: BENEVENGA NJ, CALVERT C, ECKHERT CD, FAHEY GC, GREGER JL (Eds.): Nutrient requirements of laboratory animals. National Academy Press, Washington DC, pp. 140-143

CEROVIC A, MILETIC I, SOBAJIC S, BLAGOJEVIC D, JONES DR, POZNANIC M, RADUSINOVIC M 2006: Effect of dietary zinc on the levels and distribution of fatty acids and vitamin A in blood plasma chylomicrons. Biol Trace Elem Res 112: 145-158

CEROVIC A, MILETIC I, SOBAJIC S, BLAGOJEVIC D, RADUSINOVIC M, EL-SOHEMY A 2007: Effects of zinc on the mineralization of bone nodules from human osteoblast-like cells. Biol Trace Elem Res 116: 61-72

DAVIDSON L, ALMGREN A, SANDSTROM B, HURELL RF 1995: Zinc absorption in adult humans: the effect of iron fortification. Br J Nutr 74: 417-425

GENUTH SM 1993: The hypothalamus and pituitary gland. In BERNE RM, LEVY MN (Eds): Physiology. Mosby Year Book, Missouri, pp. 897-931

GLAHN RP, WORTLEY GM, SOUTH PK, MILLER DD 2002: Inhibition of iron uptake by phytic acid, tannic acid, and ZnCl2: Studies using an in vitro digestion/Caco-2 cell model. J Agric Food Chem 50: 390-395

HOUSE WA, WASTNEY ME 1997: Compartmental analysis of zinc kinetics in mature male rats. Am J Physiol 273: R1117-R1125

KING JC, SHAMES DM, WOODHOUSE LR 2000: Zinc homeostasis in humans. J Nutr 130: 1360S-1366S

LINDER MC 1996: Copper. In: ZIEGLER EE, FILER LJ (Eds): Present knowledge in nutrition. $7^{\text {th }}$ ed. Washington D.C., ILSI Press, pp. 307-319

MACDONALD RS 2000: The role of zinc in growth and cell proliferation. J Nutr 130: 1500S-1508S

MARTIN GB, WHITE CL, MARKEY CM, BLACKBERRY MA 1994: Effects of dietary zinc deficiency on the reproductive system of young male sheep: testicular growth and the secretion of inhibin and testosterone, Reproduction 101: 87-96

MORISAWA M, MORI H 1972: Heavy metals and spermatozoan motility. Distribution of iron, zinc and copper in sea urchin spermatozoa. Exp Cell Res 70: 311-315

NOH SK, KOO SI 2001: Intraduodenal infusion of lysophosphatidylcholine restores the intestinal absorption of vitamin $A$ and $E$ in rats fed a low zinc diet. Exp Biol Med 226: 342-348

REEVES PG, BRISKE-ANDERSON M, JOHNSON L 1998: Physiologic concentrations of zinc affect the kinetics of copper uptake and transport in the human intestinal cell model, caco-2. J Nutr 128: 1794-801

REEVES PG 1998: Copper metabolism in metallothionein null mice fed a high-zinc diet. J Nutr Biochem 9: 598-601

SAKAI T, MIKI F, WARISHI M, YAMAMMOTO S 2004: Comparative study of zinc, copper, manganese, and iron concentrations in organs of zinc-deficient rats and rats treated neonatally with L-monosodium glutamate. Biol Trace Elem Res 97: 163-182

TAPIERO H, TEW KD 2003: Trace elements in human physiology and pathology: zinc and metallothioneins. Biomed Pharmacother 57: 399-411

TROOST FJ, BRUMMER RM, DAINTY JR, HOOGEWERFF JA, BULL VJ, SARIS WHM 2003: Iron supplements inhibit zinc but not copper absorption in vivo in ileostomy subjects. Am J Clin Nutr 78: 1018-1023

VALLE BL, FALCHUK KH 1993: The biochemical basis of zinc physiology. Physiol Rev 73: 79-118

YIP R, DALLMAN PR 1996: Iron. In: ZIEGLER EE, FILER LJ (Eds): Present knowledge in nutrition. $7^{\text {th }}$ ed. Washington D.C., ILSI Press, pp. 277-292

ZASLAVSKY B, UTHUS EO 2002: Response of liver and heart trace elements in rats to the interaction between dietary zinc and iron. Biol Trace Elem Res 88: 165-183 
